\title{
Does Financing Decisions Influence Investment Decisions? Empirical Evidence from Sri Lanka
}

\author{
MCA. Nazar \\ Faculty of Management and Commerce, South Eastern University of Sri Lanka, Oluvil, Sri Lanka. \\ $\triangle$ Corresponding Author: MCA. Nazar, E-mail: mcanazar@seu.ac.lk
}

\section{ARTICLE INFORMATION}

Received: December 15, 2020

Accepted: February 14, 2021

Volume: 3

Issue: 1

DOI: $10.32996 /$ jefas.2021.3.1.3

\section{KEYWORDS}

Financing decision, investment decision, GMM, Sri Lanka

\section{ABSTRACT}

This study investigates the impact of financing decision on investment decision of 198 non-financial companies listed on the Colombo Stock Exchange of Sri Lanka, eight years period from 2011 to 2018. This study employed the Generalized Method of Moments (GMM) model to estimate the regression models on panel data study. The major contribution of this study shows that the impact of financing on investment decisions of listed companies. The results of the study revealed that, the impact of total debt on changes in total asset and Tobin's $Q$ was insignificant negative and significant negative respectively. However, the impact of long term debt on changes in total asset and Tobin's $Q$ was significant negative and insignificant negative respectively. Therefore, the impact of financing decision is significantly negative on investment decision.

\section{Introduction}

The importance of corporate firms in generating a country's higher productivity and better economic growth is undeniable in today's globalization era. To play the role, the managers of the firm must confirm that their corporate funds and resources are used efficiently so that they can be transformed into productive activities. Since managers must always adopt activities that work in favour of the interest of the shareholders, they must only invest in projects that promote greater productivity and efficiency. Such projects usually need considerable investments in current technologies and promotion of products. It is the responsibility of the firm's corporate finance department to manage these financing and investment decision. Financing and investment decisions are vital for firms to safeguard operational functionality and to enable growth. As they are subject to different restrictions and opportunities, it is reasonable to assume that private and public firms behave differently in their investment and financing choices.

Basically, corporate finance deals with selection of new investment and decision as regards the manner of financing those investments. There have been widespread studies on each of these decisions. However, most of them have been carried out separately. It gives the impression inappropriate to study these two decisions in separation. Novel investments require; and decision related to it may influence the value of the firm via changes in expectations of investors. Many studies only focus on measuring the impact of financial leverage on investment decision (Modigliani \& Miller, 1958; Baker \& Wurgler, 2002; Molina, 2005). They ultimately reach contradictory conclusions using numerous approaches. The decisions of financial managers on corporate financing and investment are playing a major role determining company performance. These two financial policies are also essential for financial management in order to achieve the firm's goal enabling maximization of wealth of the shareholders.

One of the key issues in corporate finance is whether financial leverage has any impact on investment policy. The corporate world is considered by numerous market imperfections, because of transaction costs, institutional restrictions and asymmetric information. The connections between management, shareholders and debt holders will make resistances owing to agency problems and that may result in under-investment or over-investment incentives. Whenever we refer to investment, it is needed to differentiate between over- investment and under-investment.

K C AL-KINDI CENTER $\mathbf{R}$ FOR RESEARCH AND $\mathbf{R}$ DEVELOPMENT Your gateway to world-class research

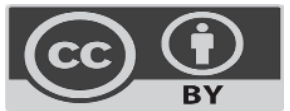

Published by Al-Kindi Center for Research and Development. Copyright (c) the author(s). This open access article is distributed under a Creative Commons Attribution (CC-BY) 4.0 license 
The main objective of the study is to investigate the impact of financing decision on investment decisions for the listed companies in Sri Lanka. Therefore, the current research contributes to the following ways: First, this paper sheds light on the issue of leverage and Investment in Sri Lanka format. Second, to the best of our knowledge, this is the key study that improves the existing line of research in emerging markets.

The remainder of this paper is organized in the following manner. The next section of the paper reviews prior research and develops the hypotheses, followed by discussion of the data, variables, method and procedures used for this empirical study. The findings and implications then follow.

\section{Literature Review and Hypothesis development}

This segment offers a review of literature on the relationship between financing decision and investment decision and development of hypotheses. The followings detail discussion on the empirical evidence of the influence of corporate financing decision on investment decision making of limited designated studies in the literature.

McConnell and Servaes's (1995) studied the relationship between corporate value, leverage and equity ownership. They reveal a positive relationship between investment and leverage among low growth firms and a negative relationship the same variables among high growth ones.

Lang et al. (1996) conducted a study using U.S. industrial firms for the years 1970 until 1989. On the basis of pooling regression, they find a significant negative relationship between financing and investment decisions for firms characterized by low growth.

Aivazian et al (2005) carried out a study to investigate the effect of leverage on investment on 1035 Canadian industrial companies for the period from 1982 to 1999 . They show leverage is negatively associated with investment and such negative association is significantly higher for firms having low growth opportunities compared to their counterparts having high growth opportunities. They examine the results strength through the use of alternative empirical models (2SLS) along with the instrumental variables technique to tackle with the issue of endogeneity existing in the leverage -investment relationship. Their results support the agency theories of corporate leverage.

Another study was done by Ridha and Bajka (2010) to investigate the relationship between investment and leverage of Swedish life science industry firms for the period from 205 to 2009. They show a negative relationship between firms' growth and their level of leverage.

The association between financing and investment policies among diversified companies are examined by Ahn et al. (2006). Their study data is gathered for the years 1982 to 1997. The results revealed that a negative impact of leverage on investments for firms having strong growth options but a positive effect of leverage for those having weak growth options. The results are consistent with McConnell and Servaes's (1995) results.

Another study, performed by Gebauer et al., (2018) on five-euro countries, has also indicated that debt levels are increased after 2008 , and firms faced difficulties with generating investment opportunities. It is vital to understand the conditions and flow of emerging markets that exhibit higher difference than the developed markets.

Existing literature demonstrates that debt can be considered as a good effective monitoring mechanism to monitor the actions of management. Therefore, researcher hypothesized that debt provides better monitoring services. In general, debt financing increases firm's value because it reduces agency costs. In levered companies, managers will only invest in projects that maximize the firm's value. Thus, debt financing policy is associated with better investment decisions. Furthermore, higher leverage produces tax shields that guide to higher firm valuation.

In general, however, the main empirical studies that have examined the influence of firm financing decision on investment show inconclusive results. Studies which find a positive relationship between financing and investment decisions (McConnell \& Servaes, 1995; Chang \& Rhee, 1990), while some other studies reveal a negative association between financing and investment decisions (Ahn et al. 2006; Ridha \& Bajka 2010). Jensen and Meckling (1976) and Jensen (1986) contend that debt can perform as a disciplining mechanism to decline free cash flow or reduce conflict of agency among managers and shareholders through implementing fixed obligations on the organization. Therefore, the researcher hypotheses that;

$\mathrm{H} 1$ : There is a significant negative relationship between company's financing decision and investment decision. 


\section{Methodology}

\subsection{Sample and Data collection}

The population of the study is 292 listed companies in the Colombo Stock Exchange (CSE). The sample data for this study consists of 198 firms listed on Colombo Stock Exchange after excluding the financial sector of 75 listed companies. The sample period of the study was 8 years from 2011 to 2018. The reason for exclusion of financial firms is they have to confirm to strict legal requirement pertaining to their financing. The data and other related information for this study are collected from the published annual reports, (CSE) Colombo Stock Exchange websites, magazines and CSE publication.

\subsection{Model Specification and definition}

This study was used General Method of Movement (GMM) regression models to test the impact of financial leverage on investment decisions of listed companies in CSE. Research model is employed to identify influence of financing decision on investment decision. Further, three control variables of tangibility, profitability and firm size used.

Model

INVESTMENT $=\alpha_{0}+\alpha_{1}$ FINANCING $+\alpha_{2}$ Profitability $+\alpha_{3}$ Firm size $+\alpha 3$ Corporate tax $+\varepsilon$

Table 3.2 Definition of the variables

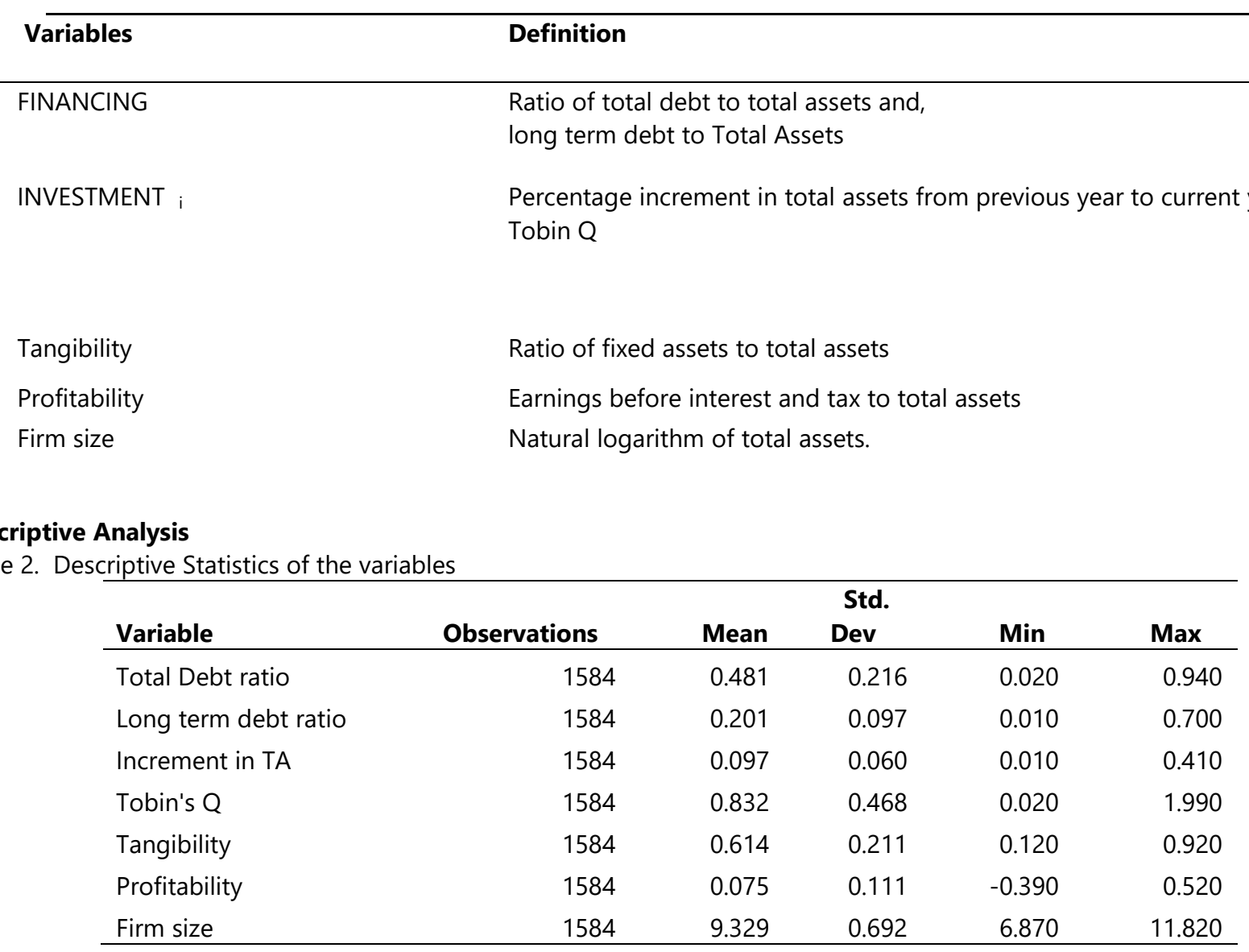

There are two measures of financing decision which are total debt ratio and long term debt ratio. The mean value for total debt ratio was 0.48 . This means that the portions of the assets of the firm are financed with the borrowing and that was utilized as it is considered as an indication of an ability of the firm in meeting obligation of those debts. This is closely consistent with the mean value of 0.499 reported for a sample of Sri Lankan listed companies by Vijeyratnam and Anandasayanan (2015). The mean value of long term debt ratio was 0.201 which is somewhat greater than the mean value 0.156 by Sangeetha and Sivathaasan (2013) for the Sri Lankan firms. 
There are two measures of investment decision which are increments in total assets, and Tobin Q. The mean value of increment in total assets shown in Table 2 was 0.097 which indicates the growth rate of investment in total assets (i.e. $9.7 \%$ ). The other measure of investment decision is Tobin's Q and the mean value was 0.832 . It is lower than the mean value of 1.27 reported for a sample of Sri Lankan firms by Guo and UdayaKumara (2012).

\section{Correlation Analysis}

Table 3. Correlation Matrix

\begin{tabular}{|l|c|c|c|c|c|c|}
\hline & 1 & 2 & 3 & 4 & 5 & 6 \\
\hline 1. Total Debt & & & & & & \\
\hline 2. Long Term Debt & 0.465 & & & & & \\
\hline 3. Increment in TA & -0.007 & 0.063 & & & & \\
\hline 4. Tobin's Q & -0.043 & -0.095 & -0.019 & & & \\
\hline 5. Tangibility & -0.042 & -0.166 & -0.011 & 0.080 & & \\
\hline 6. Profitability & -0.134 & -0.002 & 0.017 & 0.110 & -0.151 & \\
\hline 7. Firm Size & 0.054 & -0.015 & 0.016 & -0.080 & 0.122 & 0.065 \\
\hline
\end{tabular}

The bivariate correlations are used to investigate the explanatory variables and to identify independent variables with higher correlation coefficient enabling to diagnose the variable with multicollinearity problem. Table 3 provides the matrix of Pearson correlation measuring the degree of association between the variables under the study. As per the Table, correlation coefficients are not greater than 0.8 . According to Gujarati (2003), a value of greater than 0.8 could be considered as having multicollinearity problem. The highest correlation coefficient of 0.465 was observed for the relationship between total debt and long-term debt.

In order to determine whether the results of regression analyses are clear from the issues of multicollinearity, the variance inflation factor (VIF) values are examined. VIF values of more than 10 indicate that there is a multicollinearity problem (Gujarati 2003). Tables 4 show the VIF values in the financing model. The results show that there is no issue of multicollinearity in all models since the highest values of VIF was 1.12 in the investment model.

Table 5. Multicollinearity Test using VIF in the Investment Models.

\begin{tabular}{|c|c|c|c|c|}
\hline Variables & & & nent VIF & \\
\hline & Based on & nent in To & ets & on Tobin's Q \\
\hline & Model 1 & Model 2 & Model 3 & Model 4 \\
\hline Total debt & 1.04 & - & 1.04 & - \\
\hline Long term debt & - & 1.01 & - & 1.01 \\
\hline Tangibility & 1.08 & 1.09 & 1.08 & 1.0 \\
\hline Profitability & 1.07 & 1.05 & 1.07 & 1.05 \\
\hline Firm size & 1.12 & 1.11 & 1.12 & 1.11 \\
\hline Mean VIF & 1.08 & 1.07 & 1.08 & 1.07 \\
\hline
\end{tabular}




\section{Regression analysis}

Table 5. System GMM Estimation of Regression Results for Investment Decision

\begin{tabular}{|c|c|c|c|c|}
\hline & \multicolumn{2}{|c|}{ Changes in total assets } & \multicolumn{2}{|c|}{ Tobin's Q } \\
\hline & Model 1 & Model 2 & Model 3 & Model 4 \\
\hline & Coef. & Coef. & Coef. & Coef. \\
\hline TA (-1). & $0.435^{* * *}$ & $0.375^{* * *}$ & & \\
\hline Tobin's Q (-1) & & & $0.549 * \star \star$ & $0.524^{\star \star \star}$ \\
\hline TD & -0.010 & & $-0.055^{\star \star}$ & \\
\hline LTD & & $-0.027^{* * *}$ & & -0.118 \\
\hline $\mathrm{PRO}$ & $-0.025^{* *}$ & $-0.035^{* * *}$ & $0.526^{\star \star \star}$ & $0.624^{\star \star \star}$ \\
\hline Log FS & $0.006^{\star *}$ & $0.005^{*}$ & $-0.206^{\star \star \star}$ & -0.219 \\
\hline CT & $-0.843^{* * *}$ & $-0.889 * * *$ & -1.199 & $-2.948^{\star \star \star}$ \\
\hline constant & 0.006 & 0.004 & $2.281^{* * *}$ & $2.437^{* \star *}$ \\
\hline No of groups & 198 & 198 & 198 & 198 \\
\hline No of instruments & 148 & 148 & 148 & 148 \\
\hline$A R(2)$ & 0.228 & 0.440 & 0.276 & 0.305 \\
\hline Hansen test & 0.596 & 0.668 & 0.176 & 0.236 \\
\hline
\end{tabular}

*** Significant at $1 \%$ level, ** Significant at $5 \%$ level, * Significant at $10 \%$ level

Regression results of the investment decision study are discussed in four models. Model 1 and model 2 are based on changes in total assets and model 3 and model 4 are based on Tobin's Q for investment decision. The impact of total debt on changes in total asset and Tobin's Q was negatively insignificant with the co efficient value of -0.010 and negatively significant with the co efficient value of -0.055 respectively. Whereas, the impact of long-term debt on changes in total asset and Tobin's $Q$ was negatively significant with the co efficient value of -0.027 and negatively insignificant with the co efficient value of -0.118 respectively. Therefore, the impact of financing decision is significantly negative on investment decision. Hence, hypothesis $\mathrm{H} 1$ stated that there is a significant negative relationship between company's financing decision and investment decision was supported. These results are consistent with the findings of Aivazian et al. (2005). The findings also upkeep the agency theories relating to corporate leverage, specifically the theory take on that debt has a crucial role of disciplining firms with low growth opportunities. Furthermore, profitability was found to be significant negative in changes in total assets. In contrast, it has recorded significant positive effect on Tobin's Q which points out that profitable firms were expected to go for investments than the non-profitable firms. The firm size variable displayed significant positive association with changes in total assets. The results of the research indicated that firms with large size are able to invest more in investment projects compared to small firms. In contrast, firm size was displayed a significant negative association with Tobin's Q in model 3. Corporate tax has a significant negative impact on investment decision except in model 3.

\section{Conclusion and limitations}

The objective of the study is to investigate the impact of financing decision on investment decisions for the sample of 198 nonfinancial listed companies in Sri Lanka for the 2011-2018 periods. We used descriptive statistics, correlation analysis and pooled ordinary least square regression model. The regression results of OLS model indicates that financial leverage has negative and significant impact on the investment; it means that when the financial leverage ratio will increase it will cause a decrease in investment. Therefore, the capital structure plays an important role in the firms' investment policies in Sri Lanka. However, further research will good to see what happen if we embrace a simultaneous equation model whereby leverage affect investment and vice versa.

The research population comprised companies from all sectors of the economies and hence different operating environment. The study could be undertaken among companies operating in the same sector of the economy further study. 


\section{References}

[1] Ahn, S., Denis, D.J., \& Denis, D.K. (2006). Leverage and investment in diversified firms, Journal of Financial Economics, 79(2), 317-333.

[2] Aivazian, V.A., Ge, Y., \& Qiu, j. (2005). The impact of leverage on firm investment: Canadian evidence. Journal of Corporate Finance, 11, 277291.

[3] Baker, M. \& Wurgler, J., (2002), Market Timing and Capital Structure, Journal of Finance, 157, 1-32.

[4] Chang, R.P., \& Rhee, S.G. (1990). The impact of personal taxes on corporate dividend policy and capital structure decisions, Financial Management, 19(2), 21-31.

[5] Gebauer, S., Setzer, R., \& Westphal, A., (2018). Corporate debt and investment: A firm-level analysis for stressed euro area countries. Journal of International Money and Finance, 86, 112-130.

[6] Gujarati, D.N. (2003). Basic Econometrics, McGraw-Hill.

[7] Guo, Z. \& Udayakumara, KGA. (2012). Corporate governance and firm performance on listed firms in Sri Lanka. Procedia, Social and Behavioural Sciences, 40, 664-667.

a. $\quad$ https://doi.org/10.1016/j.jimonfin.2018.04.009

[8] Jensen, M.C., \& Meckling W.H. (1976). Theory of the firm: Managerial behaviour, agency costs and ownership structure, Journal of Financial Economics, 3(4), 305-360.

[9] Lang, L.E., Ofek, E., \& Stulz, R., (1996), Leverage, investment, and firm growth, Journal of Financial Economics, $140,3-29$.

[10] McConnell, J. J. \& Servaes, H., (1995), Equity ownership and the two faces of debt, Journal of Financial Economics, l39: 131-157.

[11] Modigliani, F. \& M.H. Miller, 1958. The cost of capital, corporation finance and the theory of investment. American Economic Review, 48(3), 261-297.

[12] Ridha, M., \& Bajka, D. (2010). The impact of R\&D investments on the capital structure of Swedish public life science companies, Bachelor thesis in Finance.

[13] Sangeetha M., \& Sivathaasan, N. (2013), Factors Determining Capital Structure: A Case Study of Listed Companies in Sri Lanka, Research Journal of Finance and Accounting,4(6), 236-247.

[14] Vijeyaratnam, H., \& Anandasayanan,S (2015), The Determinants of Leverage of Sri Lankan Manufacturing Companies Listed on Colombo Stock Exchange, Research Journal of Finance and Accounting, 6(5), 181-195.

[15] Molina,C.A.(2005), Are Firms Underleveraged? An Examination of the Effect of Leverage on Default Probabilities, Journal of Finance, 60(3), $1427-1459$. 